\title{
Sustainability Beyond Instrumentality Towards an Immanent Ethics of Organizational Environmentalism
}

\author{
Johnsen, Christian Garmann
}

Document Version

Accepted author manuscript

Published in:

Journal of Business Ethics

DOI:

10.1007/s10551-019-04411-5

Publication date:

2021

License

Unspecified

Citation for published version (APA):

Johnsen, C. G. (2021). Sustainability Beyond Instrumentality: Towards an Immanent Ethics of Organizational

Environmentalism. Journal of Business Ethics, 172(1), 1-14. https://doi.org/10.1007/s10551-019-04411-5

Link to publication in CBS Research Portal

\section{General rights}

Copyright and moral rights for the publications made accessible in the public portal are retained by the authors and/or other copyright owners and it is a condition of accessing publications that users recognise and abide by the legal requirements associated with these rights.

Take down policy

If you believe that this document breaches copyright please contact us (research.lib@cbs.dk) providing details, and we will remove access to the work immediately and investigate your claim. 


\title{
Sustainability beyond instrumentality: Towards an immanent ethics of organizational environmentalism
}

\author{
Christian Garmann Johnsen \\ Copenhagen Business School \\ Cgj.mpp@cbs.dk
}

\begin{abstract}
In research on organizational environmentalism, there has been a repeated call for ways to go beyond the business case for sustainability frame. While the business case frame assumes that developing eco-friendly solutions can benefit firms financially, this article highlights the importance of challenging established understandings of sustainability. To this end, I introduce Deleuze's distinction between morality and ethics. Morality involves passing judgements on the basis of values. Ethics provides an immanent evaluation of the principles by which specific solutions are considered sustainable. Analysing interviews with architects, building engineers and business developers, the article shows how these actors reflect on the values that form the basis of their practice, but also try to imagine new ways of working with sustainability. In conclusion, the article suggests that an immanent ethics of organizational environmentalism can allow for the values that inform environmental efforts in organizations to be evaluated as well as alternative visions of sustainability to be created.
\end{abstract}

Keynotes. Sustainability, organizational environmentalism, immanent ethics 


\section{Introduction}

Today, we often hear that businesses can proactively lead a transition to a greener economy by offering eco-friendly solutions that are competitive on the market. Such solutions refer to products, services and production methods that environmentally outperform conventional ones, spanning from biodegradable substitutes for plastic to recycling techniques that reduce the need to extract natural resources. Against this backdrop, it is assumed that firms that embrace green technologies will seize the business opportunities that ecological degradation engenders, thereby counteracting the impacts of man-made global warming, the loss of biodiversity, the overexploitation of natural resources, soil erosion and water contamination. This instrumental line of thinking has become a fashionable way of framing sustainability in research and practice alike. However, a growing frustration with this trend has spurred a call for an approach to 'organizational environmentalism that goes beyond "the business case", without appealing to abstract normative principles' (Painter-Morland and ten Bos 2015, p. 547; Johnsen et al. 2018; Hahn et al. 2017; Schuler et al. 2017; Painter-Morland and ten Bos 2016; Wright et al. 2013; Ergene et al. 2018). The challenge is not to formulate moral principles that attributes an inherent value to nature, but rather to explore organizational practices that reveal alternative approaches to sustainability.

For the purpose of exploring organizational environmentalism beyond the business case for sustainability frame, I invoke Deleuze's (1983) distinction between morality and ethics. As this article argues, the business case frame is a moral way of thinking. It presupposes not only that eco-friendly solutions benefit firms economically but also that sustainability can be made into a measurable quality assignable to eco-friendly solutions that fulfil certain criteria, such as the use 
of recycled materials, renewable energy sources and environmentally friendly components. By operating on this premise, the business case proceeds on the principles of measurability and profitability, assuming that sustainability can be converted into commodities that are 'calculable, comparable and exchangeable' (Nyberg and Wright 2016, p. 634). Contrary to this moral line of thinking, this article argues that immanent ethics can help us recognize the importance of opening sustainability to critical reflection. To make this argument, the article situates immanent ethics of organizational environmentalism as the ability to question the principles on which specific solutions are designated sustainable, but also as the exploration of alternative environmental and social responses (Painter-Morland and ten Bos 2015).

The contribution of this article lies in developing the conceptual distinction between morality and ethics in relation to organizational environmentalism. While scholars have called for ways of relating to organizational environmentalism that go beyond instrumentality, the Deleuzian distinction between morality and ethics provides an avenue that opens the concept of sustainability to critical reflection. The analytic utility of distinguishing morality and ethics is twofold. On one level, the concept of morality pays attention to how sustainability is understood within an organizational setting, operating as a value used to pass judgements on what is ecofriendly. But beyond this, the concept of ethics allows for an immanent evaluation of the value of sustainability by being sensitive to what is included and excluded in prevailing understandings. As such, immanent ethics can afford us new ways of thinking about sustainability without assuming that the concept exclusively involves unequivocal indicators.

The article is divided into two parts. The first part critically discusses the business case frame. To this end, I show how sustainability is predominately viewed as either a 'risk' or an 'opportunity' 
(Hahn et al. 2017), and that this schismatic framing provides the basis for an instrumental approach to sustainability. Furthermore, I show that the instrumental approach suffers from several limitations, in particular a tendency to naturalize a technical view of sustainability and thereby deprive the concept of its political and ethical dimensions (Banerjee 2008). With the help of Deleuze $(1983,1988)$, I argue that sustainability tends to operate as a value by which to pass moral judgements, but also that this value can become a target for immanent evaluation. I further show that the ability to question the environmental principles on which judgements are made is quintessential to the immanent ethics of organizational environmentalism. Consequently, this immanent ethics can allow for an evaluation of the values informing environmental and social efforts in organizations and for the creation of alternative visions of sustainability.

The second part offers the case of sustainable architecture. Here, I analyse how architects, building engineers and business developers discuss what constitutes sustainability in relation to building and construction. As I will show, sustainability does not simply feature as a preconfigured value in these narratives, but is also the target of immanent evaluation. I discuss how the individuals I interviewed for the case study reflect on various issues, such as business considerations, certifications, technology and organization, as they relate to sustainable architecture. In the concluding section, I return to the initial discussion of the business case for sustainability frame. Departing from the instrumental approach, I suggest that scholars pay attention to how organizational actors provide immanent evaluations of sustainability. As I will argue, working with sustainability is a matter not only of committing to certain principles but also of being able to assess the social setting in which one is embedded and to find alternative ways of working. 


\section{From sustainable development to instrumental thinking}

When climate change and ecological degradation began attracting widespread public attention in the 1970s, the UN launched some initiatives to map the extent of these problems, but also to propose viable responses. Central to these initiatives was the release of the Bruntland report, which coined the concept of sustainable development, defined as the ability to offer 'development that meets the needs of the present without compromising the ability of future generations to meet their own needs' (WCED 1989). The report stresses that we need to rethink 'the global economy and global ecology together in new ways' (WCED 1987, pp. 2, 15), replacing environmentally destructive economic growth with sustainable development. In the 1990s, this discourse found its way into organization and management studies, raising awareness of the relationship between ecological degradation and businesses (Gladwin et al.1995). It became clear that businesses bore much of the responsibility for ecological degradation through their toxic waste dumping, CO2 emissions and natural resource extraction (Shrivastava 1994). In recent decades, however, the discourse has taken an optimistic turn.

Although some have seen ecological degradation as a threat to their business basis, many view it as an opportunity for firms to create market-based solutions that can be profitable while also addressing environmental concerns. As specified in the UN Global Compact initiative, for example, firms can 'leverage opportunities' by concentrating on the 'development and diffusion of environmentally friendly technologies'. ${ }^{1}$ The prevailing mantra is that ecological degradation can be counteracted by businesses that develop and implement eco-friendly solutions. As firms

\footnotetext{
${ }^{1}$ Source: https://www.unglobalcompact.org/what-is-gc/our-work/environment
} 
strive to address ecological degradation, they should reconcile environmental concerns with economic profits. From corporate environmentalism (Ambec and Lanoie 2008) to eco-efficiency (DeSimone and Popoff 2000) to sustainable entrepreneurship (York and Venkataraman 2010), many approaches assume that there is no intrinsic conflict between generating profits and preserving the environment. On the contrary, environmentally conscious firms can introduce products, services and production methods that reduce ecological footprints while simultaneously generating financial gains (Lash and Wellington 2007).

\section{Against instrumental thinking}

Recently, the business case for sustainability frame has come under intense scrutiny. PainterMorland and ten Bos (2016) maintain that instrumental thinking permeates this frame, a thinking that rests upon a series of distinctions, in particular the oppositions between 'subjects'/'objects', 'facts'/'values' and 'means'/'ends'. By this token, nature is reduced to an external object: 'the environment' (Banerjee 2003), which represents a bundle of resources that can be managed and controlled. Firms, in turn, are considered as subjects that can either preserve or exploit their habitat. Understood in this way, organizational members can only relate to environmental degradation as either a threat to their industry or a business opportunity (Hahn et al. 2014). Investigating the implications of subscribing to instrumental thinking, Painter-Morland and ten Bos (2016) convincingly argue that this mode of reasoning suffers from a number of limitations that ultimately compromise our understanding of organizational environmentalism.

In instrumental thinking, no 'intrinsic value' (Hahn et al. 2017) is ascribed to the natural

environment, which is considered valuable only insofar as it can be used as a means to a financial 
end (Schuler et al. 2017). As a result, Painter-Morland and ten Bos note, 'morality is rendered technical' $(2016$, p. 552) - that is, our moral responsibility to nature is converted into a technical procedure for generating profits by reducing environmental footprints. This technical morality means, however, that nature is subsumed to the economy: 'development is sustainable only if it is profitable, it is sustainable only if it can be transacted through the market' (Banerjee 2003, p. 173). Put differently, environmental courses of action are only legitimate insofar as they contribute to the firm's bottom line. As such, the business case frame deprives the sustainability concept of its political and ethical dimensions (DesJardins 2016). For this reason, Banerjee (2008) warns against conflating sustainable development with corporate sustainability. Moreover, corporate efforts seldom match the severity of ecological degradation, and the business case frame might incline firms to adopt a specific conception of sustainability that merely serves to reinforce their environmentally destructive business models, according to Wright et al. (2013).

In light of the critique levelled at instrumental thinking within management and organization scholarship on sustainability, calls for alternative ways of conceptualizing environmental efforts in organizational settings have grown louder (Schuler et al. 2017; Painter-Morland and Bos 2016; Johnsen et al. 2018; Dyllick and Hockerts 2002; Hahn et al. 2017; Ergene et al. 2018). Ergene et al. (2018), for instance, offer the perspective of 'ecologies of sustainable concerns', which incorporates a broad view on the social and environmental dimensions of sustainability but also draws attention to the process of 'living well with others'. Hahn et al. (2017) develop a paradox perspective on organizational environmentalism that points to the conflict between social, environmental and economic considerations in organizations. To further help develop perspectives beyond the business case frame, I consider how immanent ethics can enrich research 
on organizational environmentalism, allowing us to develop an alternative to the instrumental conception of sustainability.

\section{Deleuze on ethics and morality}

So far, we have looked at how the business case frame underlies sustainability discussions in organization and management studies, but also explored the limitations of this approach. In the following, I will borrow Deleuze's distinction between ethics and morality in order to think about organizational environmentalism beyond the business case frame. Although ethics and morality are commonly used interchangeably in everyday language, business ethics scholars often carefully distinguish between the two terms. For example, Fisher shows that morality is often considered the 'principles or rules of moral conduct as defined by society' (2004, p. 397), which is to say that morality signifies the set of norms governing what is right and wrong, good and bad, within a social setting. Unlike morality, ethics is frequently assumed to consist of 'reflecting on the nature and justifications of right and wrong' (Fisher 2004, p. 397), providing a foundation for morality by explicating the reasons why certain courses of actions are considered either right or wrong.

For Deleuze, ethics is not about justifying morality, and this argument underlies his critique of ethics as it is conventionally understood. For example, Deleuze views Kant's thinking as conservative, as it merely seeks to justify the moral principles already prevailing in society. This is why he notes that 'Kant's critique is justification, it begins by believing in what it criticizes' (1983, p. 90). Deleuze instead believes that ethics does not enable us to justify moral principles, but rather lets us explore the ways of living that moral values encompass, offering alternatives to 
them and helping us imagine new forms of life beyond those currently at hand. Deleuze therefore provides us with a different understanding of the distinction between ethics and morality. Inspired by Spinoza and Nietzsche, he maintains that ethics and morality differ in their respective relationships to values.

Morality, Deleuze (1983) learns from Nietzsche, consists of passing judgements based on normative values. Conversely, Spinoza tells Deleuze (1988) that ethics involves an immanent evaluation of the values that govern our daily lives. For Deleuze, morality is a 'system of Judgement' that takes its point of departure in the existence of preconfigured normative 'values' (1988, p. 23). Values are principles for passing judgements. People use such values as principles by which to judge right from wrong, correct from incorrect, true from false and the beautiful from the ugly. Put differently, specific values always pervade the moral assessments by deeming certain courses of action right or wrong. The following example aids in elucidating the relationship between values and morality. If we state that wind turbines are sustainable while coal plants are not, then our judgements proceed on the basis of a specific value. This value, in turn, equates sustainability with renewable energy sources that neither exhaust scarce resources nor increase carbon emissions. Adhering to this value, we can characterize renewable energy sources like tidal stream generators, solar panels or wind turbines as ecologically friendly while discarding fossil fuel power plants as environmentally unjustifiable.

In this way, the value of sustainability allows us to pass moral judgements, deeming certain energy sources environmentally friendly while others not. This is why a set of values will incline us to prefer one state of affair over other (Florea et al. 2013). If we accept that values play an inevitable role in the judgements we pass, then the limitation of morality, according to Deleuze 
(1988), is that it fails to question the values that underlie our judgements. Hence, morality operates on the basis of values without questioning to what extent they deserve our appreciation and devotion. However, Deleuze believes that critique is about questioning the 'value of values' (1983, p. 1) - that is, questioning the principles that form the basis for the various judgements we pass. For this purpose, he introduces the concept of ethics.

Contrary to morality, ethics does not commit to a set of preconfigured normative values that constitute the basis for passing moral judgements. Quite the opposite, ethics provides an immanent evaluation of the values that remain embedded in the 'modes of existences' (Deleuze 1988, p. 23) that we inhabit and that inform our moral judgements. For Deleuze, values are neither naturally given nor subjectively constructed but remain embedded within fields of social norms and moral codes that surround us. However, such social norms and moral codes do not simply dictate the actions that people take. Instead, values remain open to critique insofar as normative principles can be contested. Ethics, according to Deleuze, does not discount all the normative principles that inform our way of living, for that would be tantamount to disregarding all existing values without offering any alternative. Rather, he believes we need to question existing values so that we can explore alternative ways of living. Echoing Nietzsche, he thus writes that we should be able to 'create new values' that open up 'new possibilities of life' (1983, p. 85, 103, original italics; see Hjorth and Holt 2016; Painter-Morland, 2011).

New possibilities of life do not necessarily consist of dramatic interventions in established conventions or revolutionary upheavals of dominating orders, but may also involve subtle variations in everyday habits or a different approach to solving an everyday dilemma. These possibilities can signify a novel way of collaborating with others; an attunement to the 
opportunities that present themselves in a social setting; or a new understanding of a spoken term. Central to ethics is the capacity to not simply take the world for granted, but instead retain the capacity to imagine how things could be otherwise. As Clarke and Holt explain, 'ethics concerns less the outcome of human activity than the capacity to distance ourselves from, and critically imagine alternatives to, the ways we organize ourselves' (2010, p. 319).

The difference between ethics and morality amounts to the difference between 'immanent evaluation' and 'transcendent judgement' (Smith 2012). While morality asks 'What must I do?', ethics asks 'What can I do?' (Smith 2012, p. 176) or, as May wonders, 'How might one live?' (2005). Ethics explores the range of actions, ways of speaking and thinking available within a certain mode of existence (Smith 2012, p. 147). A mode of existence is a style of life or a way of being. It refers to the subjectivity produced within a social setting (Pedersen 2008, p. 174). Such subjectivity is not prefigured by a pre-existing essence (e.g. 'human nature' or 'cogito'), but is the outcome of a process merging the individual and the social. In this process, ethics allows us to evaluate the mode of existence we inhabit. For example, ethics allows us to ask: if we subscribe to a set of moral values, what mode of existence are we committed to?

The task here is not to judge such modes of existence from the viewpoint of normative values but to evaluate them by exploring their implications, looking at what is included and excluded in such ways of life. Such evaluations, following Deleuze's (1988, p. 23), substitute the moral distinction between 'Good-Evil' with a distinction between 'good-bad'. While 'bad' indicates the condition of being 'cut off from its power of acting' (Smith 2012, p. 157), the good signifies, in the words of Deleuze, 'everything that increases or enhances our power of acting' (1988, p. 71). However, Deleuze's (1988, p. 71) emphasis on ethics as the process of enhancing the power to 
act can easily be misinterpreted as a quantitative manner of gaining the power to either exploit or control others. While immanent ethics, as Smith (2012) explains, seeks to intensify a mode of existence, such intensification must be grasped qualitatively.

A return to the previous example serves to illustrate how immanent ethics might unfold. As we saw, configuring the value of sustainability as renewable energy allows us to judge tidal stream generators, solar panels or wind turbines as being ecologically friendly. However, this form of moral reasoning prohibits us from questioning the value of energy efficiency as such. To enter into an ethical mode of thinking, we therefore need to evaluate the value of the sustainability that grounds our judgement. With this aim in mind, we can explore how an ambitious focus on renewable energy sources diverts our attention from other pivotal aspects of sustainability, such as the social arrangements that energy efficiency is designed to reinforce. To open up for ethical thinking, we could wonder why we actually need energy efficiency, thus questioning why we have organized our lives in ways that require us to rely on excessive amounts of energy to maintain our current lifestyles. We might also explore other aspects of sustainability beyond energy efficiency, including material extraction and the social aspects of our existence, thereby relating to sustainability in new ways. Such forms of ethical thinking might enable us to understand sustainability differently. Viewed from the perspective of ethics, an unconditional commitment to specific values restricts our perception and deprives us of the ability to imagine alternative courses of action (Smith 2012).

In the following, I will show how the Deleuzian distinction between ethics and morality can shed light on how organizational members engage with sustainability. Deleuze's view on ethics and morality is more than a normative induction encouraging us to explore new possibilities of life, 
for it can also be analytically useful for understanding how organizational members struggle with the value of sustainability in their quest for new approaches to environmental and social challenges. Hence, the capacity for ethics is not an extraordinary event solely preserved for theoretical speculation, but rather remains 'part of everyday practices by which and in which subjects give form to their lives' (Weiskopf 2014, p. 155). Next, I will explore how organizational actors use the value of sustainability to pass judgements, but also how they call into question the values that inform their practices in order to envision new ways of acting, speaking and thinking.

\section{Case selection}

To analyse how organizational members reflect on the value of sustainability, I have chosen to use the case of sustainable architecture, as an array of environmental challenges confront the building and construction industry. Building and construction in Europe is estimated to be responsible for $40 \%$ of all energy and $33 \%$ of all water consumed, for $40 \%$ of all materials extracted as well as for a large share of all waste produced. In total, construction is responsible for approximately $20-35 \%$ of all ecological degradation. ${ }^{2}$ The energy used for heating and cooling buildings, the widespread use of resource- and energy-intensive construction processes and materials as well as the massive amount of discarded residual material from construction and demolition represent major challenges that the building and construction industry must tackle.

\footnotetext{
${ }^{2}$ Source: Energistyrelsen (2015): Bæredygtigt byggeri, first edition, 978-87-93071-94-0
} 
The case presented here focuses on the Greater Copenhagen region of Denmark. Over the course of the previous decades, Denmark has seen the enactment of stricter environmental building and construction policies, such as tighter requirements for energy efficiency. To lessen the extensive ecological footprint left by building and construction, actors within the sector increasingly profile themselves as offering green buildings. Thus, architectural firms, engineering companies and contractors are increasingly adopting energy efficiency technologies, recycling procedures and waste reduction techniques. This environmental awareness is also reflected in the proliferation of voluntary environmental standards, such as the Danish version of the German Society for Sustainable Building (DGNB) certification developed by the Green Building Council. The sector has also established networks, industry conferences and innovation projects for sustainable architecture and construction, bringing actors together for the purpose of finding ways to address the heavy burden that energy- and material-intensive modern construction processes place on the environment.

\section{Methodological considerations}

The primary data for this study was acquired through a series of semi-structured, in-depth interviews with 19 architects, building engineers and business developers, all of whom work with architecture and sustainability in the Greater Copenhagen region of Denmark. Among the respondents, twelve are formally educated architects, two are building engineers and five are business developers working for architect firms or interest organizations. Each interview lasted between 45 and 90 minutes. On two separate occasions, two people were interviewed simultaneously, while the other interviews were all done individually. In three instances, two persons from the same firm were interviewed. The rest worked for different organizations. My 
intent with contacting each organization was to interview professionals who worked with sustainability and architecture, including architects, building engineers and business developers working for architect organizations.

Although the respondents' organizations approach sustainability differently, they all have explicit sustainability profiles. These profiles are reflected in the organizations' external and internal communication, but also in the specific work they conduct. For example, one of the architects interviewed was responsible for a unit that developed sustainable building materials, while another managed a division focused on building energy-efficient houses. Some of the respondents were licenced to certify buildings according to the DGNB certification standard. The interviews focused on how the respondents perceived sustainability; what specific initiatives they had developed to address environmental challenges; what they saw as the main obstacles to more sustainable construction; and the future prospects for sustainable architecture.

After the interviews were conducted, recorded and transcribed, I carefully read all the interviews in order to gain an overview of the various themes, topics and issues that reoccurred across them. At this stage of the analytic process, it became clear that while all the respondents shared a concern for sustainability, their ideas diverged when it came to how to address the social and environmental challenges confronting the construction industry. For example, some stressed the importance of focusing on building materials while others emphasized building design. Moreover, they often remained critical not only towards dominant construction practices, but also about the industry's general understanding of sustainability. In the following stage, I used sticky notes to manually assign labels to central quotes. The labels marked the themes addressed in the given quotes. I then organized the material according to the different categories, which I 
constructed by searching for dominant themes. Under each category in which I had grouped relevant quotes, I was able to compare how the respondents discussed similar issues, including, for example, the meaning of sustainability, the way that construction projects are organized, the economic incentives for construction, the use of technology in sustainable construction projects and so forth.

The second step consisted of analysing the material grouped under each category. During the analytic process, I found the Deleuzian distinction between ethics and morality helpful in capturing how sustainability is a value that can be immanently evaluated. In this way, Deleuze's conceptual distinction between morality and ethics helped me make sense of the material and hence examine how the respondents related to different aspects of sustainability. For example, I looked at how the respondents tried to evaluate the concept of sustainability by enacting a distance towards predominate understandings. I also explored how they tried to imagine new ways of working with sustainability. While the material certainly invites multiple readings, I will show how the distinction between ethics and morality can shed new light on organizational environmentalism.

Deleuze's method is the invention of concepts that afford a 'new way of dividing up the world' (2004, p. 22). This is pragmatic insofar as concepts should 'enable more useful descriptions of the world' (Patton 2003: 58). According to Deleuze, creating concepts does not necessarily involve inventing something entirely new, but can also involve transposing an established concept from one context to another. Experimenting with concepts can allow us to unlock new experiences. In this way, he draws a close connection between 'radical experimentation and experience' (Alliez 2004, p. 29-30). Our experience is premised on the concepts we endorse, but 
unanticipated experiences can equally allow us to form new concepts. Conceptual experimentation requires an engagement activated outside the realm of philosophy (Massumi 2010). The relationship between philosophy and activities outside it constitute what Deleuze calls an 'encounter': something 'in the world forces us to think' (2001, p. 139). I have formed this analysis in the encounter between Deleuze's immanent ethics and the case of sustainable architecture. Inspired by this experimental approach, I use Deleuze's conceptual distinction between ethics and morality to develop an analytic perspective on organizational environmentalism that goes beyond the business case frame. Thus, the study aims to provide analytic insight into how the distinction between ethics and morality can inform our understanding of organizational environmentalism, focusing on how actors evaluate the concept of sustainability in relation to architecture.

\section{Analysis}

The analysis is divided into four parts. The first part focuses on attempts to create a distance to moral values by immanently evaluating the value of sustainability. The second part zooms in on the dilemmas experienced by the respondents, but also explores how they try to imagine alternative ways of relating to materials and organizing construction processes. The third part discusses how the respondents questions the use of technology to improve the environmental performance of buildings. The final part explores immanent ethics as an engagement in selfformation.

Creating distance: Questioning the meaning of sustainability 
For many respondents, UN's definition of sustainable development served as the point of departure of their work with sustainable architecture. By this account, sustainable architecture consists of creating designs that equally balance the economic, social and environmental aspects of building and construction. Hence, sustainable architecture should ensure the social well-being of users, preserve the ecosystem and be financially stable. A sustainable building should, for example, at once accommodate the demands of the occupants, be constructed with eco-friendly materials and have low maintenance costs. While this 'holistic' approach, a term that many of the respondents used, ensures that sustainability is not reduced to a single indicator for distinguishing sustainable from unsustainable architecture, they often felt that keeping a broad outlook on sustainability was a constant challenge.

As some respondents explained, people frequently associated sustainable architecture with the use of immediately visible solutions, such as grass roofs or solar panels on buildings. However, as one business developer clarified, a building might look green on the surface, but still lack the capacity to imitate nature's usual functions, such as dealing with surface runoff water or regulating temperature. One architect experienced that sustainable architecture was associated with a concern for energy consumption. Thus, in her words, 'we just need to accept that many equate sustainability with energy insulation.' Another architect said that 'we have always understood [the concept of sustainability] in broad terms, but it has been difficult, because our clients and the market have not'. She elaborates on this by saying: 'To be able to take part in the discussion, we need to speak the language that everyone focuses on, namely kilowatt hours per day.' 
Configuring the value of sustainability as energy efficiency provides the basis for judging what architectural practices and initiatives are appropriate. Thus, once sustainable architecture becomes a matter of optimizing energy consumption, then the focus strengthens on solutions such as insulation methods that will minimize the need for heating or as the use of solar panels that can generate clean energy. This creates a moral way of reasoning in which the value of sustainability is used to judge what initiatives and practices that should be developed and implemented in order to achieve sustainable architecture. However, while the respondents believed that focusing on energy consumption was a crucial aspect of sustainable architecture, they insisted that sustainable architecture could not be reduced to energy efficiency, thereby striving to create a way to think about sustainability beyond this frame. One architect said:

Energy consumption is a major focus, but there are other factors as well. Obviously, you can achieve a really impressive energy record by living in a thermo tank, but you will probably be unable to stand living there for long. Therefore, factors other than energy consumption need to be considered when a house is built.

Immanent ethics presupposes the creation of a distance to the moral values that traverse a social setting (Weiskopf 2014). By creating this distance, one can open up a space for evaluating the effects produced by the predominant moral values, making it possible to gain insights into the 'mode of existence' - that is, the ways of thinking, talking and acting - produced by moral values. As some of the respondents stressed, focusing on energy consumption was attractive because it makes sustainability measurable, making it possible to portray environmental initiatives as an economic investment. Thus, in the words of one architect: 
For a long time, we talked about environmental considerations and energy efficiency. You could relate to them. They're clear, and they're measurable, and you can see their consequences, not only in terms of the $\mathrm{CO} 2$ figures but also in terms of money. Economic sustainability - that is, total economy - is also something that you can clearly relate to, because it's numbers $[\ldots]$ In our age, it's very important to compare everything and measure things, and then make improvements on the basis of the units measured.

Distance is created by assessing the form of life subscribed by moral values. Such evaluations do not entail passing judgements, but rather understanding the modes of reasoning involved in a moral framing of sustainability. As we see above, a concentration on energy efficiency rests on two principles: measurability and profitability. Measurability assumes that sustainability can be turned into an objective quantity, enabling comparisons between buildings based on their energy consumption. Profitability assumes that sustainability has to be valorized on the market. For instance, the monetary savings gained from lower heating expenses can be presented as a business case. While these two principles guide many of their work practices, sustainable architecture is not only about measuring performance and collecting points towards certification.

Beyond this view, the architect quoted above explained that for her, sustainable architecture is not only about creating solutions that were measurable, but also about creating 'something that the end-user can sense, feel or experience'. For her, sustainable architecture was about being attentive to the way that buildings stimulate the senses, creating fragrances, resonances, moods and perceptions. In the case of fragrance, this concern did only arise because sustainable buildings should not fume toxic particles that was unhealthy for the users, but also because certain materials, such as wood, had aromas that people could appreciate. In this way, she tried to 
make new connections, linking sustainability to the experience of people who use buildings. Viewed from the perspective of immanent ethics, connecting sustainability and experience becomes an attempt to explore a different way of working with sustainable architecture. However, she did not abandon the idea of making sustainability measurable, but insisted that the challenge was to 'measure that which can only be experienced'. At the same time, she discussed how many of the social aspects of sustainable architecture were 'difficult to measure', for example, how building inhabitants experience the indoor climate.

Although technical solutions are required to provide accurate measurements, the challenge of deciding what to measure remains an ethical issue. This ethical issue can only be addressed if one refrains from taking the concept of sustainability for granted and instead remains open to evaluating how that sustainability is understood within a social setting. As can be seen here, questioning established concepts by creating a distance to moral values is a prerequisite for immanent ethics. In sustainable architectural practices, buildings and constructions are constantly be judged on the basis of their specific features (e.g. solar panels) and measurable effects (e.g. energy consumption). Morality figures here as a mode of reasoning that uses predefined criteria for separating the sustainable from the unsustainable. Yet, working with sustainable architecture presupposes that one can think beyond this mode of reasoning by reflecting on the limitations of reducing sustainability to single factors. As one architect noted, sustainability and architecture can 'always be discussed and called into question', and it is this ability to evaluate prevailing practices that immanent ethics allows us to apprehend. Here, immanent ethics becomes a practice of evaluating what is included and excluded in any conceptualization of sustainability by enacting a distance to dominant values. 
Experiencing tensions: Imagining how things can be otherwise

Immanent ethics is not only about questioning dominant understandings by creating a distance to moral values, but also about detecting dilemmas and experimenting with new forms of acting, speaking and thinking. The respondents experienced a multitude of dilemmas in relation to working with sustainable architecture, such as the tension between short- and long-term commitments (Hahn et al. 2014; Hahn et al. 2017; Painter-Morland et al. 2017). Yet, some respondents believed that construction projects were currently organized in a way that forestalled sustainable architecture. For example, one business developer noted:

The construction industry has been marked by tunnel vision - the various actors are not good at talking to each other and collaborating. We are getting better all the time, but if we are to become more sustainable, then we need to think in a completely different way. (Business developer)

She illustrated the lack of collaboration in this manner:

I think that architects just design something they think is beautiful, and then they are perceived as 'just sitting there on their high horses and designing something that will gain them prestige', without actually engaging in a dialogue with the engineers that need to develop [the design] and that say, 'That's not possible, that's not possible.' [The architects respond] that 'Now you're destroying my project!' The contractor makes a 
turnkey contract, taking all the work away from the others because they cannot cooperate. (Business developer)

The complications that would arise due to a lack of cooperation between different professional groups, such as architects and engineers, she experienced, would increase the use of turnkey contacts, where one actor could control the entire process. As the quote above illustrates, a typical conflict is between architects and engineers. Architects' focus on design and aesthetics ('just sitting there on their high horses and designing something that will gain them prestige') may clash with the engineers' focus on building technical aspects ('That's not possible, that's not possible'), making the architect feel that the vision for the design is compromised ('Now you're destroying my project!'). However, while such tensions could not easily be resolved, many of the respondents sensed that they had to find ways of navigating the incompatible demands with which they were confronted. In many cases, sustainable architecture had to be presented as a financial investment that carried the instrumental benefits of using socially and environmentally friendly design features. One building engineer said:

I think it's something that you have to convince a developer that they are getting something extra - they pay more, but they get higher rent payments and higher quality. If it's an office building with some employees, then they become more productive.

To show the economic advantages of sustainable architecture, many respondents employed instrumental means-ends logics: creating a good indoor climate, for example, could reduce employees' stress levels, reusing materials could lower material procurement costs and building 
low-energy houses could cut heating expenses. Yet, the instrumental framing of sustainability, which focuses on the economic advantages gained by subscribing to eco-friendly solutions, fails to capture actors' attempt to reimagine and explore new ways of thinking, speaking and acting. For many of the respondents, making an effort to invent new, viable architectural practices remained key. This could involve, as one respondent discussed, experimenting with new forms of construction project organization. One architect had been involved in a project that avoided engaging separate actors for each project phase, opting instead to include the various actors in all the phases, from the design through to the construction. The point was that everyone 'felt responsibility for making a difference' (Architect), which could then ensure that building maintenance issues, for example, were considered already in the design phase.

Many materials from dismantled buildings are recycled, but often in the form of 'down-scaling' crushed concrete, for example, ends up as road fill. However, the challenge is to reuse materials while preserving their inherent qualities - something that would require a rethinking of the linearly organized construction process. A plan for how to put building materials to new uses after possible demolition must be made at the design phase. Reusing old building materials, respondent clarified, requires that they be 'designed for disassembly' - that is, materials must be collected in a way that allows them to be separated from one another without being destroyed. Such practices involve a new way not only of relating to materials, but also of thinking and speaking. As such, the perspective has shifted from seeing building material functionality as diminishing over time to developing a new set of practices (e.g. constructing buildings with visible joints that allow for disassembly), but also to what one architect referred to as a new form of care: 
For us architects, in relation to material planning, we need a new form of care, a new way of thinking about our material choices that relate to the life cycle [of the building]. Another huge challenge is that we need a better understanding of how buildings work in practice and how people use buildings. Much of this is contextual. The operation and the planning of projects must be more closely connected. This is where value is created. (Architect)

The form of critical reflection expressed here is immanent rather than transcendent because it is not been formulated from the outside - that is, from a judgmental attitude grounded in external standards - but from a concern expressed from within the practice of sustainable architecture. Such reflection entails thinking about what architecture has to offer sustainability and thinking differently about how natural resources are used. For example, the recycling of building materials, such as the reuse of concrete or bricks, can give buildings a unique aesthetic expression which was central to some of the respondents sustainability work. However, while many of the respondents sought a new way of working with materials, there was no consensus about what constitutes sustainability. For example, some felt that wood was the ideal sustainable building material, its being potentially organically grown and biologically degradable, while others suggested the durability of concrete was an environmental benefit.

The lack of consensus might be conceived of as hindering the establishment of common standards for achieving sustainable architecture - something that a conventional take on ethics, understood as providing the basis for morality, ought to provide. However, from an immanent ethics perspective, the lack of consensus provides a basis for experimenting with different approaches. An immanent ethics of organizational environmentalism refuses to accept that we 
already know what forms of sustainability are possible. Following Spinoza, Deleuze insists that 'you do not know beforehand what good and bad you are capable of; you do not know beforehand what a body or a mind can do, in a given encounter, a given arrangement, a given combination' (1983, p. 125). Instead, this is something that must constantly be tested. Viewed from this perspective, the immanently ethical question of sustainability becomes: What does a commitment to sustainability enable us to do? In this way, Deleuze's immanent ethics is pragmatic, because there is no set of external standards from which to judge, only an injunction to continuously experiment with the possible. This is where immanent ethics departs from the instrumental line of thinking underlying the business case frame. The business case frame presupposes that we already know what sustainable architecture is. Rather than relying on a fixed definition, we need to see how working with sustainability within architecture is evolving.

\section{Evaluating styles of life: Contesting technology}

Alongside the focus on making sustainability measurable and profitable, a growing interest has been seen in developing and implementing new technologies that can improve buildings' environmental performance. For instance, 'active' houses, as they are commonly known, produce more energy than they consume because high-tech solar panels are incorporated in their design. In this way, the focus on technologies is intimately linked with measurability insofar as specific technological devices are what produce numerically represented results. Although this focus follows a trend towards a technological optimism that assumes we can decouple economic growth and environmental degradation by inventing new technologies (Jackson 2016), many respondents reflected on the limitations of placing sustainability in a technological framework. For example, one architect said: 
When we are talking about sustainability, it often becomes talk about technology: buildings should have better energy sources, better solar panels, district heating and so on. Of course, we appreciate all the technologies that are available, and we can learn a lot about using them, but we would rather make a house that doesn't need solar cells, because the sunlight enters in the right places and the electricity consumption is optimized. It's about geometry. I think it's crucial that we use our core area of expertise to calculate in such a way that we don't make a sick house in need of a technology cure. Sometimes, I think we are hypnotized - not by technology as such, but by the idea that you can just take something out of a box and put it somewhere, just like a cell phone. But what we are making are building technologies that are specific to this precise place on earth. This is important to me.

Technologies are often considered universal devices that can be applied to any given building to optimize its environmental performance. Some respondents believed that to think beyond this framework and evaluate the effects of placing sustainability in a technological framework, they had to address the underlying environmental problems of modern construction instead of treating the symptoms. They further suggested that many of the environmental challenges confronting the construction industry resulted from modern construction processes that created a need for implementing technologies. For example, one architect explained that densely insulated buildings generated moisture problems that, in turn, were prevented by installing vapour barriers. However, this solution creates the additional challenge of low air circulation in buildings, an issue some solved by installing electronic ventilation systems. Ultimately, he said, the building process has reached the point where we 'add so many things and make the construction process so 
complicated that it becomes more and more cumbersome'. He therefore claimed that instead of creating new technologies that could solve the problems arising in modern buildings, the industry should create sustainable buildings that did not necessitate the application of technological solutions.

A technological line of thinking overlooks how a building remains a specific construction, located at a specific place and used by specific people. For some of the respondents, working with sustainability does not require the embrace of new technologies, but rather a reinvigoration of traditional building techniques within a contemporary setting - techniques that are considered more environmentally responsible and socially flexible than modern ones. They also said that one should avoid reducing sustainability to mere work with technical devices that can optimize aspects like energy consumption, but instead take into account the entire design of the building. One architect said:

We can, of course, make a good building with room for all sorts of technologies, but the most interesting thing is when sustainability becomes an architectural discipline, and we can do the right groundwork for the building. That is, [when] we are allowed to make something that has some good rooms, good materials, with due consideration to how solutions can change over time. And you can use your building and understand your building. So, the framework that we use for all our projects is that we say: 'Dear developer, try to understand that sustainability is not just about your ventilation systems and your solar cells; it's also about making sure that the groundwork is good. The better it is, the more sustainable your project becomes, no matter how much technology you put into it.' 
Here the relationship between architecture and sustainability is reconsidered. Instead of viewing sustainability as a component being added to architecture, requiring designers, engineers and developers to take into account environmental and social aspects of buildings alongside architectural ones, the architect above tries to consider how the basic layout of buildings - what she refers to as the 'groundwork' - involves sustainability. The choice of materials, the location of the building and the design of the interior, for example, has consequences for how the inhabitants experience the building, but also for the environmental footprint it leaves. Therefore, architecture should be considered a sustainability discipline, according to her. This concern for design has been apparent in the creation of flexible buildings that could serve different purposes without requiring extensive refurnishing. In this way, it has been possible to ensure that buildings could avoid being dismantled because they were considered outdated. However, the crux here is not a critique of technology, but more fundamentally a concern for the subject position of the architect within the organization of the modern construction process.

\section{Self-formation: Rediscovering the architect}

Modern construction processes are based on industrial management principles like division of labour, involving different professional groups. In this delegation of responsibility to specific professional groups, some noted, the architect exists as a 'consultant' that offers the specific service of preparing designs, but often in collaboration with other technical specialists, such as building engineers. However, the respondents emphasized that ascribing this identity to architects still gave rise to considerable limitations, as they could be engaged in the task of 'drawing, 
drawing, drawing' (Architect), without having much influence on the actual practice of construction.

Viewed from this perspective, working with sustainability becomes an occasion for rethinking what architecture has to offer modern construction processes. Engaging in such reflection involves an ethical practice of 'self-formation': a concern for the form of life of the architect. For example, one architect was involved in a project that was trying to merge design and construction in order to more closely connect two often-isolated processes. This project was aimed not only at developing a new production method that could integrate the design and construction phases in construction processes, but also at enacting a new identity - that is, at endeavouring to create a new understanding of what an architect could do. Instead of being an architect associated with drawing designs, this architect took inspiration from the Renaissance figure of the 'master builder', a pre-industrial figure who was not detached from the construction process, but involved in all phases. He explained:

This is the dream when you want to become an architect: you want to build a house. In that way, if we go back in time, then you talked about the master builder. The architect that drew the design was also present at the building site. He was the great conductor. Today, the architect leaves the project fairly early on and hands over much to the contractor. We want to mix it [e.g. design and construction] together and simplify it.

From an immanent ethics perspective, the existential mode of being an architect - the style of life that it implies and the existence ascribed to this subject position within the construction process is open for negotiation. This negotiation concerns what roles, responsibilities and capacities 
architects should be ascribed within the organization of the construction process. Poldner, Branzei and Steyaert (2019) call such ethical practices of self-formation 'styling': subjects give form to their lives by combining available discursive resources with their sense of self-identity. Subjects are not predetermined by social structures and discursive formations, but are able to craft their self-identify by drawing on the available resources. Such new self-understandings - for example, the architect as a master builder - provide the basis for imagining new ways of working with sustainable architecture. In this instance, reinvention takes the form of rediscovery.

Yet, we can also discern a limitation of immanent ethics here. While the respondents strive to enact a distance to established values, this distance always occurs against the backdrop of the established identities they occupy. Hence, their critique is based on the professional identity of being an architect, which involves a concern for building design irreducible to a technical procedure. According to Loacker and Muhr (2009), this constitutes the limitation of ethical responsibility insofar as subjects are never able to achieve complete self-transparency. Social actors can only attend to an identity on the basis of the discursive resources available. At the same time, a double movement is at play here: while social actors are constituted by social structures, they can also influence those structures. This gives rise to a tension in which immanent ethics remains embedded. On the one hand, immanent ethics involves a capacity to create a distance that allows alternatives to be imagined. On the other hand, however, any attempt to create such a distance occurs against the backdrop of values that constitute basis for immanent ethics. The creation of immanent ethics in organizational environmentalism neither ignores nor embraces this tension, but rather acknowledges the double movement at stake in sustainability.

\section{Concluding discussion}


In this article, I have explored the conceptual distinction between morality and immanent ethics in relation to organizational environmentalism. From the perspective of immanent ethics, working with sustainability takes place in the tension between ethics (immanent evaluation) and morality (transcendent judgement). Such work entails a commitment to certain values that serve as the basis for passing judgements, while simultaneously retaining the capacity for questioning prevailing values. Immanent ethics create a distance towards moral values that opens up a horizon for imaging how things could be otherwise. Yet, such distances always occur against the backdrop of the context in which one is and remains embedded. Immanent ethics is about creating new connections, linking sustainability to new ways of thinking, speaking and acting. In the case analysed, we can see how the respondents try to connect sustainability with a myriad of concerns, such as the experience of those who use buildings; the concern for the geometry of buildings, including the arrangement of space and location of the building; the use, lifespan and recyclability of building materials; the organization of construction projects; and the role of the architect within construction projects. In this way, the respondents try to think beyond a narrow view on sustainability, refusing to condense the value into one indicator. Here immanent ethics can be positioned as the capacity to experiment with alternative ways of understanding sustainability that go beyond energy efficiency; to imagine alternative organizational forms that allow environmental and social challenges to be addressed from new angles; and to engage in self-formation as a concern for the form of one's life. In this way, the distinction between immanent ethics and morality can shine a stronger light on organizational environmentalism than a merely instrumental approach. 
While considerable criticism has been levelled at the instrumental line of thinking underlying the business case for sustainability frame (Painter-Morland et al. 2017; Painter-Morland and Bos 2016; Hahn et al. 2014, 2017; Schuler et al. 2017), we still lack alternate conceptions of organizational environmentalism. The challenge here consists of more than just thinking beyond a 'win-win' logic that elevates economic values above environmental and social ones (Hahn et al. 2017). It also means thinking beyond purely quantifiable indicators. As Painter-Morland and ten Bos (2016) suggest, the tendency to 'measure dominates corporate life in ways that make an alternative relationship between various types of beings impossible to envisage' (2016, p. 558). Unless environmental efforts can produce quantifiable results (e.g., lower $\mathrm{CO} 2$ figures and higher monetary value), they fail to be registered in the business case frame. Yet, Painter-Morland and ten Bos believe that organizational environmentalism should consist of building relationships centred on avoiding ecological degradation in the first place rather than on adopting technical solutions aimed at remedying unsustainable organizational practices.

Despite the fact that Painter-Morland and ten Bos challenge the 'hegemony of instrumentalism', they refuse to accept that businesses are the only 'bad guys' (2016, p. 560) responsible for ecological degradation. They call for a nuanced approach, highlighting the organizational processes that can foster social and environmental responsiveness, but also the processes that prevent us from building sustainable relationships. The daunting spectre of ecological degradation is a pessimistic prospect for humans, but it can also enable us, according to Wright et al., to 'make sense of the world differently' (2013, p. 654). This capacity lies at the heart of immanent ethics - a capacity that might help us gain a new understanding of organizational environmentalism. 
As Robinson (2004) notes, the concept of sustainability is often accused of suffering from vagueness, its lacking a clear definition and operationalized measurements. While some call for establishing a common understanding of the concept, Robinson suggests that sustainability involves a 'constructive ambiguity'. The challenge with boiling the concept down to a narrow definition is that it effectually excludes alternative perspectives. For this reason, Robinson sees an 'important political opportunity' in keeping the concept of sustainability open. Deleuze's distinction between ethics and morality allows us to push this argumentation further. Any configuration of the concept of sustainability invites a moral line of thinking in which values are used to pass judgements. Yet, immanent ethics is the attempt to open up for new understandings by exploring what remains latent but still unrealized within current modes of thinking, acting and speaking. In this way, the matter becomes not only what sustainability currently represents but also what it might 'become' (Massumi 2010, p. 13), thereby releasing the potential for alternatives latent in the concept. It is, in the words of Massumi, an 'act of resistance: to the way things are, out of concern for how they may become' (2010, p. 13, original italics).

An immanent ethics of organizational environmentalism has both analytic and normative implications that ultimately coincide with the concern for exploring new ways of thinking, speaking and acting in relation to sustainability. On an analytic level, the creation of new modes of existence occurs through experimentation: the ability to actively envision, imagine and test new possibilities of life. However, as Smith emphasizes, instead of being restricted to a privileged place or intellectual domain, 'one can never predict in advance where these loci of experimentation will occur; one can only be attentive to the unknown that is knocking on the door' (2012, p. 158). This line of argumentation has an important implication as regards an immanent ethics of organizational environmentalism. We need to change, following Smith, the 
analytic 'orientation away from the universal and towards the singular; and away from the historical towards the actual' (ibid. 158-159, original italics). The actual is not 'what we are, but rather what we are becoming' (ibid. 159). In turn, we need to draw our analytic attention towards areas where new ways of working with sustainability are occurring. Or, to use the words of Painter-Morland and ten Bos, we should pay attention to the 'emergence of alternative forms of organizing, which allow for new forms of sociality and environmental responsiveness to emerge' (2016, p. 559).

Having a focus on the singular in relation to organizational environmentalism will involve being attentive to forms of addressing social and environmental issues that contain new ways of acting, speaking and thinking. An example might be a new way of working with materials that do not consider them as resources that lose their value over time, but instead having the capacity of gaining new dimensions through reprocessing, adding aesthetic qualities by being put into a new setting. Another example might be ways of working with sustainability that places relationships in the centre of attention. Consider the case of plastic pollution, which is a pressing environmental problem today. To address this problem, it might be important to not only invent recycling techniques that allows for plastic to be contained within a closed circular system, but also rethink the way that plastic is currently integrated into the network of relations which we daily take part of. It might seem difficult to imagine going grocery shopping without plastic serving a central role. But this is perhaps because we do not consider ways of acting, speaking and thinking opens up for new relationship between ourselves and the food we consume.

The analytic focus of this article converges with a normative orientation that substitutes the moral distinction between 'Good/Evil' with the ethical distinction between 'good/bad'. What is 'good' 
or 'bad' is not determined by external standards, but refers to the ability of a form of life to unfold its potential or go to the limit of what it can do. Translated into the organizational environmentalism setting, a 'bad' approach to sustainability would restrict our ability to think differently about what constitutes sustainable ways of living. For example, the business case frame only recognizes solutions that generate both economic and environmental value. This approach is problematic because it implicitly disregards environmental initiatives that fail to make immediate profits (Hahn et al. 2014, 2017). In contrast, what we, with Deleuze, can term a 'good' approach to organizational environmentalism enhances organizational members' capacities to speak, act and think in response to social and environmental challenges. Such an approach should, for example, give organizational members what Christensen et al. call a 'license-to-critique' - the ability to 'observe and challenge existing ideals, assumptions and practices' (2017, p. 250).

A typical critique levelled at Deleuze's philosophy is that although he tries to defy transcendent principles, he nevertheless retains a value-laden orientation. In doing so, Deleuze risks reproducing what he seeks to overcome, namely a moral line of thinking embedded in normative values. Rather than refusing such claims, Patton suggests that Deleuze's thinking explicitly 'privilege the processes of creative transformation' (2000, p. 2), thereby proceeding on the basis of normativity. Yet, such normativity, Patton continues, is grounded in an immanent line of thinking that explores the values that stabilize any social configuration, but also their latent and inherent potential for change. Hence, we can situate immanent ethics as the attempt to experiment with sources for creative transformation that lie embedded within the institutions that govern a social setting. 'What "must" always remain normative', Smith elaborates, 'is the ability to 
critique and transform existing norms: that is, to create the new' (2012, p. 347). An immanent ethics of organizational environmentalism rests upon this assumption.

\section{References}

Alliez, E. (1993/2004). Signature of the World: What is Deleuze and Guattari's Philosophy?.

London: Continuum.

Ambec, S. and Lanoie, P. (2008). Does It Pay to Be Green? A Systematic Overview. The Academy of Management Perspectives 22(4), 45-62.

Banerjee, S. B. (2003). Who Sustains Whose Development? Sustainable Development and the Reinvention of Nature. Organization Studies 24(1), 143-80.

Banerjee, S. B. (2008). Corporate Social Responsibility: The Good, the Bad and the Ugly. Critical Sociology 34(1), 51-79.

Christensen, L. T., Morsing, M. and Thyssen, O. (2017). License to Critique: A Communication Perspective on Sustainability Standards. Business Ethics Quarterly 27(2), 239-62.

Clarke, J. and Holt, R. (2010). Reflective Judgement: Understanding Entrepreneurship as Ethical Practice. Journal of Business Ethics 94(3), 317-31.

Cohen, L., Wilkinson, A., Arnold, J., Finn, R. (2005). Remember I'm the bloody architect!' Architects, organizations and discourses of profession. Work, employment and society, 19(4), $775-796$.

Deleuze, G. (1983). Nietzsche and Philosophy. Columbia University Press, New York, NY.

Deleuze, G. (1988). Spinoza: Practical Philosophy. City Lights Books, San Francisco, CA.

Deleuze, G. (2001). Difference and Repetition. (P. Patton, Trans.).London \& New York: Continuum. 
Deleuze, G. (2004). Desert Island and other texts - 1953-1974, New York: Semiotext(e)

DeSimone, L. D. and Popoff, F. (2000). Eco-Efficiency: The Business Link to Sustainable Development. MIT Press, Boston, MA.

DesJardins, J. (2016). Is It Time to Jump off the Sustainability Bandwagon?. Business Ethics Quarterly 26(1), 117-35.

Dyllick, T. and Hockerts, K. (2002). Beyond the Business Case for Corporate Sustainability. Business Strategy and the Environment 11(2), 130-41.

Ergene, S., Calas, M. B., and Smircich, L. (2018): Ecologies of sustainable concerns:

Organization Theorizing for the Anthropocene. Gender, Work and Organization 25(3), 222-245.

Fischer, J. (2004). Social Responsibility and Ethics: Clarifying the Concepts. Journal of Business Ethics 52(4), 381-90.

Florea, L., Cheung, Y. H. and Herndon, N . C. (2013). For All Good Reasons: Role of Values in Organizational Sustainability. Journal of Business Ethics 114(3), 393-408.

Gladwin, T. N., Kennelly, J. J. and Krause, T. S. (1995). Shifting Paradigms for Sustainable Development: Implications for Management Theory and Research. Academy of Management Review 20(4), 874-907.

Guy, S. and Farmer, G. (2001). Reinterpreting Sustainable Architecture: The Place of Technology. Journal of Architectural Education 54(3), 140-48.

Hahn, T., Figge, F. Pinkse, J. and Preuss, L. (2017). A Paradox Perspective on Corporate Sustainability: Descriptive, Instrumental, and Normative Aspects. Journal of Business Ethics, June, 1-14.

Hahn, T., Preuss, L., Pinkse, J. and Figge, F. (2014). Cognitive Frames in Corporate Sustainability: Managerial Sensemaking with Paradoxical and Business Case Frames. Academy of Management Review 39(4), 463-87. 
Hjorth, D. and Holt, R. (2016). It's Entrepreneurship, Not Enterprise: Ai Weiwei as Entrepreneur. Journal of Business Venturing Insights 5 (June), 50-54.

Hoffman, A. J. and Henn, R. (2008). Overcoming the Social and Psychological Barriers to Green Building. Organization \& Environment 21(4), 390-419.

Jackson, T. (2016). Prosperity without Growth: Foundations for the Economy of Tomorrow. 2nd edition. Routledge, New York, NY.

Johnsen, C. G., Olaison, L. and Sørensen, B. M. (2018). Put Your Style at Stake: A New Use of Sustainable Entrepreneurship. Organization Studies 39(2-3), 397-415.

Lash, J. and Wellington, F. (2007). Competitive Advantage on a Warming Planet. Harvard Business Review 85(3), 94-102.

Loacker, B. and Muhr, S. (2009): How can I become a responsible subject? Towards a oractuce based ethics of responsiveness, 90: 265-277.

Massumi, B. (2010). What Concepts Do: Preface to the Chinese Translation of A Thousand Plateaus. Deleuze Studies 4(1), 1-15.

May, T. (2005). Gilles Deleuze: An Introduction. Cambridge University Press, New York, NY. Nyberg, D. and Wright, C. (2016). Performative and Political: Corporate Constructions of Climate Change Risk. Organization 23(5), 617-38.

Painter-Morland, M. 2011. Rethinking Responsible Agency in Corporations: Perspectives from Deleuze and Guattari. Journal of Business Ethics 101(1), 83-95.

Painter-Morland, M. and ten Bos, R. (2016). Should Environmental Concern Pay Off? A Heideggerian Perspective. Organization Studies 37(4), 547-64.

Painter-Morland, M., Demuijnck, G. and Ornati, S. (2017). Sustainable Development and WellBeing: A Philosophical Challenge. Journal of Business Ethics, August, 1-17. 
Pedersen, M. (2008). Tune in, break down, and reboot - new machines for coping with the stress of commitment, Culture and Organization, 14(2): 171-185.

Poldner, K., Branzei, O. and Steyaert, C. (2018): Fashioning ethical subjectivity: The embodied ethics of entrepreneurial self-formation, Organization, 26(2): 151 -174

Rasche, A. (2010). The Limits of Corporate Responsibility Standards. Business Ethics: A European Review 19(3), 280-91.

Schuler, D., Rasche, A., Etzion, D. and Newton, L. (2017). Introduction: Corporate Sustainability Management and Environmental Ethics. Business Ethics Quarterly 27(2), 213-37.

Shrivastava, P. (1994). CASTRATED Environment: GREENING Organizational Studies. Organization Studies 15(5), 705-26.

Smith, D. W. (2012). Essays on Deleuze. Edinburgh University Press, Edinburgh.

Walker, A. (2015). Project Management in Construction. John Wiley \& Sons, Hoboken, NJ.

Weiskopf, R. (2014). Ethical-aesthetic Critique of Moral Organization: Inspirations from

Michael Haneke's Cinematic Work. Culture and Organization 20(2), 152-74.

World Commission on Environment and Development (WCED). (1989). Our Common Future. Oxford University Press, Oxford.

Wright, C., Nyberg, D., De Cock, C. and Whiteman, G. (2013). Future Imaginings: Organizing in Response to Climate Change. Organization 20(5), 647-58.

York, J. G. and Venkataraman, S. (2010). The Entrepreneur-environment Nexus: Uncertainty, Innovation, and Allocation. Journal of Business Venturing 25(5), 449-63. 